Journal of Natural History

\title{
Nest architecture in polydomous grass-cutting ants (Acromyrmex balzani)
}

\section{Nádia Caldato, Roberto da Silva Camargo, Luiz Carlos Forti, Ana Paula Protti de Andrade \& Juliane Floriano Santos Lopes}

To cite this article: Nádia Caldato, Roberto da Silva Camargo, Luiz Carlos Forti, Ana Paula Protti de Andrade \& Juliane Floriano Santos Lopes (2016) Nest architecture in polydomous grass-cutting ants (Acromyrmex balzani), Journal of Natural History, 50:25-26, 1561-1581, DOI: 10.1080/00222933.2016.1166529

To link to this article: https://doi.org/10.1080/00222933.2016.1166529

央 Published online: 11 Apr 2016.

Submit your article to this journal $\pi$

III Article views: 80

View Crossmark data $₫$ 


\title{
Nest architecture in polydomous grass-cutting ants (Acromyrmex balzani)
}

\author{
Nádia Caldato ${ }^{a}$, Roberto da Silva Camargo a Luiz Carlos Fortia, \\ Ana Paula Protti de Andrade ${ }^{a}$ and Juliane Floriano Santos Lopes ${ }^{b}$ \\ aLaboratório de Insetos Sociais-Praga, Departamento de Produção Vegetal, Faculdade de Ciências

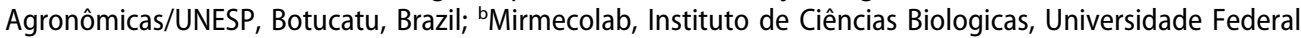 \\ de Juiz de Fora, Juiz de Fora, Brazil
}

\begin{abstract}
Acromyrmex balzani is a grass-cutting ant species frequently found in Cerrado areas. However, little is known about the architecture of the polydomous nests of this ant. Fifteen $A$. balzani nests located in a cerrado region in Botucatu, São Paulo, Brazil, were studied. The polydomous nests were studied in three ways. First, we investigated the architecture in nests moulded with cement and without moulding. Second, we performed an aggressiveness test among workers in different subnests and nests. Third, we excavated the nest and collected the colony to measure the population, verifying the existence or not of a queen in all nests. A cement mould was made of seven nests to permit better visualization of internal structures such as chambers and tunnels. Eight nests were excavated without moulding and white neutral talc was used to highlight the parts of the nests. After excavation, the depth and dimensions (length, width and height) of the chambers were measured. The results showed that the nests had a single entrance hole whose structure consisted of straw and other plant residues in winter. Mounds of loose soil, if present, were found 6$48 \mathrm{~cm}$ from the hole. The number of chambers containing fungus ranged from one to five, with the first being found a few centimetres beneath the ground surface $(4 \mathrm{~cm})$ and the last up to a maximum depth of $160 \mathrm{~cm}$. The length of the tunnels ranged from 12 to $28 \mathrm{~cm}$. These tunnels were built in a vertical or inclined position, leading to the chambers. No waste chambers were found, with the waste being deposited externally. Additionally, the polydomous nests contained one to eight subnests. In the aggressiveness test, when concolonial workers were confronted, no aggressiveness was observed. In contrast, when allocolonial workers were confronted, there was a high incidence of aggression among them. Excavation of polydomous nests showed only one queen for each polydomous nest, i.e. subnests with a single queen. Our study contributes to a better understanding of the so far unknown nest architecture of the polydomous grass-cutting ant $A$. balzani.
\end{abstract}

\section{ARTICLE HISTORY}

Received 21 September 2015

Accepted 9 March 2016

Online 11 April 2016

\section{KEYWORDS}

Grass-cutting ants; nest; social insects

CONTACT Roberto da Silva Camargo camargobotucatu@yahoo.com.br E Laboratório de Insetos Sociais-Praga, Departamento de Produção Vegetal, Faculdade de Ciências Agronômicas/UNESP, Caixa Postal 237, 18603-970 Botucatu, SP, Brazil

๑ 2016 Informa UK Limited, trading as Taylor \& Francis Group 


\section{Introduction}

Nest architecture is an important factor for the development of ant colonies and is specific for each species. The nests can be less elaborate such as those above ground, or more complex such as underground or arboreal nests (Hölldobler and Wilson 1990). Atta and Acromyrmex have the most elaborate nests; however, these nests are different and vary in morphology and size between the two genera and even between species of the same genus. For example, the nests vary in terms of their internal complexity and are larger, reaching on average 8 million individuals and up to $7 \mathrm{~m}$ in depth in Atta species. The number of chambers ranges from hundreds to thousands and mounds of loose soil are always found on the ground surface (Weber 1972; Fowler et al. 1986; Della Lúcia and Moreira 1993; Moreira et al. 2004a, 2004b).

In contrast, the nests of Acromyrmex species are smaller, with an average of 175,565 individuals. Underground nests can reach a depth of $5 \mathrm{~m}$. The number of chambers ranges from 1 to 26 . Some species make above-ground nests covered with straw and plant residues, while others build underground nests that can be covered with loose soil or are sometimes inconspicuous (Gonçalves 1961, 1964; Pereira-da-Silva et al. 1981; Navarro and Jaffé 1985; Della Lúcia and Moreira 1993; Andrade 2002; Forti et al. 2006; Verza et al. 2007).

The main structural function of a nest is to protect the queen, offspring and adults from natural enemies and other dangers, in addition to providing appropriate microclimatic conditions for maintenance of the colony and cultivation of the symbiotic fungus in the case of ants of the tribe Attini (Roces and Kleineidam 2000; Bollazzi and Roces 2002; Moreira et al. 2004a, 2004b).

The type of deposition of loose soil and the ventilation system of the nest guarantee the high internal humidity of the chambers (90\%) observed in Atta vollenweideri nests located in open areas (Kleineidam and Roces 2000). The volume of loose soil is another important characteristic in the study of colony architecture, but has been undervalued by researchers. According to the studies of Tschinkel (1987, 1999a, 1999b, 2003, 2005), Mikheyev and Tschinkel (2004) and Moreira et al. (2004a, 2004b), the internal architecture of ant nests comprises two basic elements: vertical shafts and horizontal chambers. Variations in the shape, size, number and arrangement of the basic elements result in the typical architecture of different species. Observations made by Sudd (1982) highlight the important function of these constructions not only in ant nests, but also in nests of other social insects, to protect their descendants and queen from natural enemies and other dangers, to control the distribution of food between descendants, and to regulate the microclimate.

The nests of Acromyrmex balzani are small and consist of two to four interconnected underground chambers. The connection with the surface is made through a vertical shaft. The fungus grows on grossly chopped pieces of grass that measure $2-5 \mathrm{~mm}$ in length (Gonçalves 1961). The first fungus chamber is found at a depth of approximately $5 \mathrm{~cm}$, whereas the second is located at a depth of $10-20 \mathrm{~cm}$ and the third at a depth of $35-60 \mathrm{~cm}$. The queen of this species generally occupies the last fungus chamber, which measures about $10 \mathrm{~cm}$ in diameter and $6 \mathrm{~cm}$ in height. The population of the nest is small and consists of a small number of adult workers (Gonçalves 1961). Externally, A. balzani nests exhibit simple straw tubes about $20 \mathrm{~cm}$ from the entrance and a mound 
of excavated soil resembling half the crater of a leaf-cutting ant nest. Others have a mound of loose soil forming a semi-circle on the side of the entrance (Gonçalves 1961). With respect to excavation, ant nests have been little investigated and most studies only describe the structure of the nests and provide little information about their architecture (Tschinkel 2004). However, it is known that some species are polydomous, i.e. colonies live in physically separated yet socially connected subnests (Hölldobler and Wilson 1990).

In more detailed descriptions of insect nests, some authors have used internal moulding techniques with dental plaster, zinc and aluminium and other methods of reconstitution (Tschinkel 2003, 2004, 2005; Mikheyev and Tschinkel 2004; Halley et al. 2005; Moser 2006). However, particularly in the case of leaf-cutting ants, the technique most widely used for nest reconstruction is cement moulding, in which a mixture of cement and water is poured into the entrance holes of the nest. This technique has been used for Atta (Jacoby 1935, 1950; Moreira et al. 2004a, 2004b) and was described for the first time by Verza et al. (2007) for nests of Acromyrmex rugosus rugosus.

Although several studies have investigated the nest architecture of leaf-cutting ants, addressing external and internal structures, little is known about these structures in species of the genus Acromyrmex. Therefore, the objective of the present study was to provide a detailed description of the architecture of the polydomous nests of the grasscutting ant, Acromyrmex balzani, using excavation and cement moulding. In addition, we performed an aggressiveness test among workers in different subnests and polydomous nests and, we excavated the nest and collected the colony to measure the population, verifying the existence, or not, of a queen in all nests.

\section{Material and methods}

\section{Acromyrmex balzani nests}

For this architectural study, $15 \mathrm{~A}$. balzani nests containing subnests were moulded and excavated. The nests differed in terms of the size of the area of loose soil and diameter of the entrance hole. Some nests were moulded using cement, which permitted a better visualization of internal structures such as chambers and tunnels. Other nests were excavated without moulding and the structures of these nests were highlighted with white neutral talc. The experimental area chosen for the excavations was the Fazenda Santana, located near Fazenda Lageado, Unesp-FCA, Botucatu, SP, Brazil (22 $53^{\prime} 09^{\prime \prime}$ S; $48^{\circ}$ $26^{\prime} 42^{\prime \prime}$ W). The excavations were conducted between December 2008 and December 2009.

The external and internal structures of the nests were evaluated, as well as the deposition of loose soil, diameter of the entrance holes, dimension of the nest and nesting.

\section{Excavation technique}

The nests were excavated by opening a small trench around the nest, digging from the outside to the inside and getting deeper according to the appearance of chambers. Once the chambers were found, white neutral talc was sprinkled for better visualization. 
The chambers were counted, photographed and their depth beneath the ground surface, length, height and width were measured.

Some nests were moulded with cement for better visualization of their structures, facilitating the study of nest architecture. For moulding, a mixture of cement and water at a proportion of $2: 10(\mathrm{~kg} / \mathrm{l})$ was pumped into the holes of each nest using a method modified from Jacoby (1935), Moreira (1996, 2001), and Verza et al. (2007).

The nests were excavated 1 week after they had been filled with cement using small manual tools to avoid destruction of the nests. After excavation, the nests were photographed and the following measurements of the chambers and tunnels were obtained: dimension (width, height and length) and depth beneath the ground surface. The mean, standard deviation and range of the chamber and tunnel measures were calculated.

\section{Aggressiveness test}

Aggressiveness tests were conducted among workers of polydomous nest, i.e. several subnests (concolonial) and among workers of different polydomous nests (allocolonial). We used five polydomous nests, which were subsequently excavated. The hypothesis is that there is no aggression among workers of subnests, i.e. a polydomous nest.

We observed the behaviour of three workers, when the workers were confronted. These workers were placed in an arena (pot) $125 \mathrm{ml}, 6 \mathrm{~cm}$ wide and $5 \mathrm{~cm}$, internally coated with a FLUON band (polytetrafluoroethylene - liquid slip) to prevent the ants leaving the pot bottom. Three replicates were made for each observation for a period of 5 minutes each. According to Ichinose et al. (2007), levels of aggression between different nests workers can vary from just opening the jaws or holding the legs of another worker with a jaw to more aggressive action, such as biting the head of another worker until death. In this study, we analysed only if there was aggression among nests or not. Hence the parameters analysed were:

(1) Not aggressive - workers only touched the antennae in an act of recognition.

(2) Aggressive - workers opened their jaws as a repellent act to another worker either to bite the other's head or to the death of one of them.

After all tests, nests were excavated to confirm the presence of one or more queens. A chi-square test was applied to the results, where at $\mathrm{HO}$ the proportions were equal between the observed and expected, with $a=5 \%$.

\section{Determination of colony population}

Five polydomous nests were excavated to check for one or more queens, as well as the determination of the colony population. For this purpose, the contents of each nest were immediately weighed and sacrificed by freezing in a common freezer, to prevent the eggs from being destroyed. The entire nest population was measured by counting, using a stereoscopic microscope. We used a simple linear regression for fungus volume and number of workers and colony population. 


\section{Results}

\section{External architecture}

The $A$. balzani colonies possessed several underground subnests, which were relatively small for the genus Acromyrmex. The subnests consisted of few chambers. Externally, the subnests had only one irregular entrance on the ground, which had a diameter of 1.0$2.5 \mathrm{~cm}$ (Table 1).

In the warmer months of the year (January and February), loose soil removed from the tunnels and galleries was observed near the entrance hole, forming mounds of soil. Only one entrance hole was observed in the other months of the year in each subnest, with or without a straw tube at the entrance (Figure 1).

The distance from the hole of deposition of the loose soil, if present, ranged from 6 to $48 \mathrm{~cm}$ (Table 1). The mean length, width and height of the mounds of loose soil observed around A. balzani nests were $10.1,8.3$ and $2.2 \mathrm{~cm}$, respectively (Table 1 ).

\section{Internal architecture}

The chambers overlapped and arranged vertically and were connected by a single shaft. The chambers had a round or oval shape and irregular contours and the internal part was sometimes smooth. The chambers varied in terms of height $(2-13 \mathrm{~cm})$, width (3$15 \mathrm{~cm}$ ) and length $(4.5-14 \mathrm{~cm}$ ) and variations were observed between nests (Table 2). The length of the chambers could not be measured in nests moulded with cement. The depth of the chambers beneath the ground surface also varied, ranging from 4 to $26 \mathrm{~cm}$ for the first chamber and from 30 to $160 \mathrm{~cm}$ for the last chamber.

Table 1. Number and dimensions (mean) of the external structures of Acromyrmex balzani nests moulded with cement.

\begin{tabular}{|c|c|c|c|c|c|c|}
\hline Nest & Subnest & $\begin{array}{l}\text { Length of mound } \\
\text { of loose soil }(\mathrm{cm})\end{array}$ & $\begin{array}{l}\text { Width of mound } \\
\text { of loose soil }(\mathrm{cm})\end{array}$ & $\begin{array}{l}\text { Height of mound } \\
\text { of loose soil }(\mathrm{cm})\end{array}$ & $\begin{array}{l}\text { Hole } \\
\text { diameter } \\
(\mathrm{cm})\end{array}$ & $\begin{array}{l}\text { Distance between mound } \\
\text { of loose soil and entrance } \\
(\mathrm{cm})\end{array}$ \\
\hline 1 & 1 & 20 & 16.2 & 3.5 & 1.3 & 10 \\
\hline \multirow[t]{2}{*}{2} & 1 & 20 & 16 & 4 & 2.5 & 14 \\
\hline & 2 & 21 & 12 & 5 & 2.4 & 48 \\
\hline \multirow[t]{3}{*}{3} & 1 & 8 & 17 & 2.5 & 0.7 & 32 \\
\hline & 2 & 17 & 14 & 3.8 & 1.2 & 13 \\
\hline & 3 & 23 & 14 & 2.8 & 0.9 & 30 \\
\hline 4 & 1 & 18.2 & 14.3 & 4.7 & 1.2 & 14.8 \\
\hline 5 & 1 & 10.3 & 10.4 & 5.3 & 1.1 & 35 \\
\hline \multirow[t]{8}{*}{6} & 1 & 0 & 0 & 0 & 0.7 & 10 \\
\hline & 2 & 0 & 0 & 0 & 1.2 & 0 \\
\hline & 3 & 0 & 0 & 0 & 1 & 11 \\
\hline & 4 & 0 & 0 & 0 & 1.3 & 6 \\
\hline & 5 & 0 & 0 & 0 & 1 & 6 \\
\hline & 6 & 0 & 0 & 0 & 0.5 & 10.5 \\
\hline & 7 & 16 & 14.5 & 3.5 & 2 & 0 \\
\hline & 8 & 0 & 0 & 0 & 0.9 & 20 \\
\hline 7 & 1 & 18 & 12 & 2 & 1.3 & 20 \\
\hline Total & & 171.5 & 140.4 & 37.1 & 21.2 & 280.3 \\
\hline Mean & & 10.1 & 8.3 & 2.2 & 1.2 & 16.5 \\
\hline SD & & 9.39 & 7.3 & 2.05 & 0.56 & 63.45 \\
\hline
\end{tabular}

SD: standard deviation. 

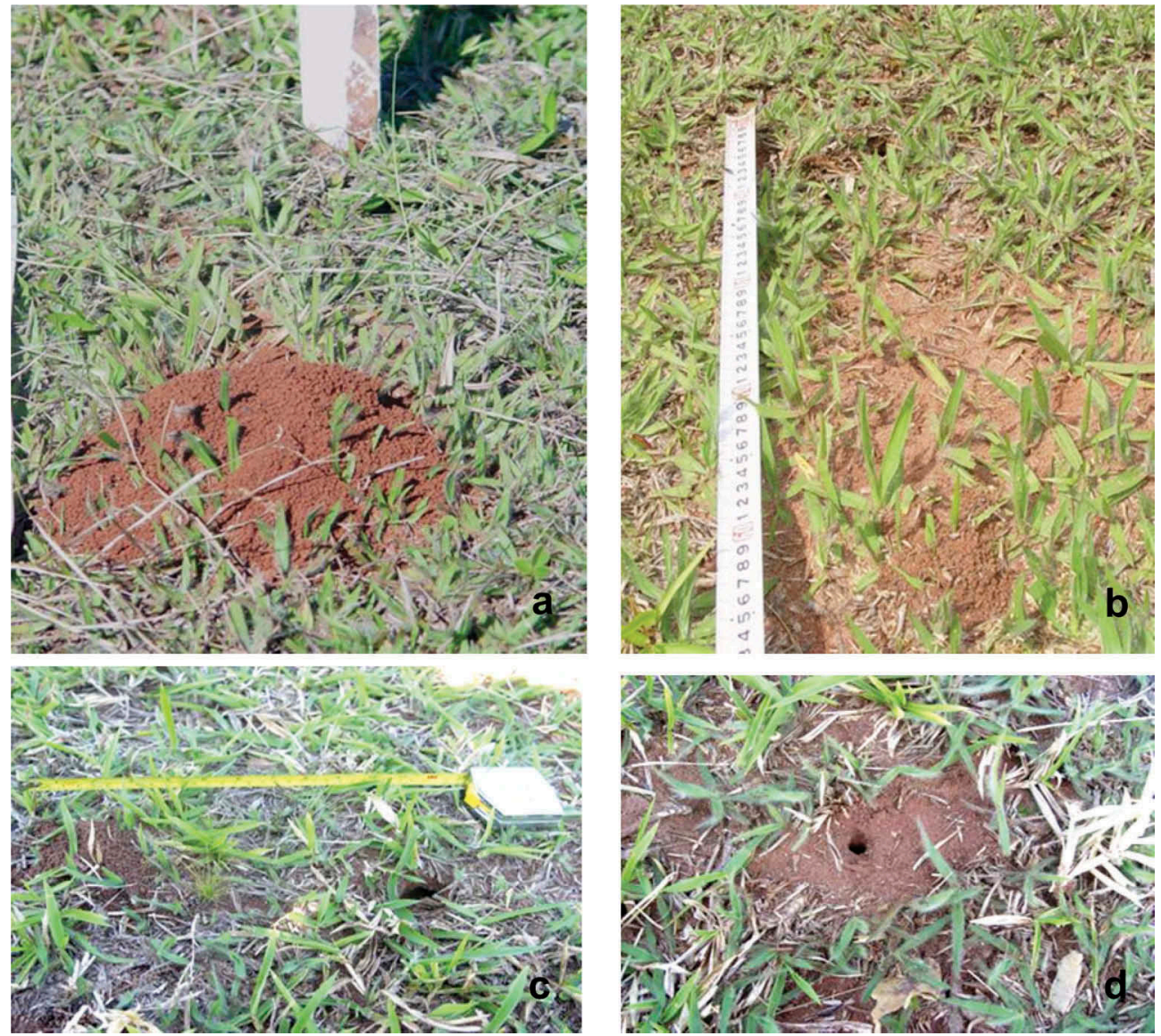

Figure 1. External view of Acromyrmex balzani nests. (A, B) Distance between the holes and mound of loose soil. (C, D) Nests without an exposed mound of loose soil. Scale: $40 \mathrm{~cm}$.

The number of chambers per subnest ranged from two to five (Table 2). The tunnels were cylindrical, regular and short, with their length $(4.0-135.0 \mathrm{~cm})$ and width $(0.6-$ $2.5 \mathrm{~cm}$ ) varying between chambers. The mean length and width of the tunnels are shown in Table 3. Only the last tunnel, which led to the last chamber, was generally longer (Table 4).

There was a small first tunnel between the entrance hole and first chamber, which was generally short and wider than the other tunnels $(2.5 \mathrm{~cm})$. This tunnel was linked to the first fungus chamber, which was located immediately beneath the entrance hole. All excavated nests were not very deep, ranging from 30 to $160 \mathrm{~cm}$ in depth (Figure 2). The nests moulded with cement did not contain internal lateral shafts connecting one subnest to the other.

\section{Nesting and waste deposition}

The subnests of the same colony occurred close to each other $(0.92-4.12 \mathrm{~m})$, but the distance between one colony and another was greater, reaching $8.1 \mathrm{~m}$. The nests were 
Table 2. Number and dimensions (mean, standard deviation and range) of the chambers and maximum depth of Acromyrmex balzani nests moulded with cement.

\begin{tabular}{|c|c|c|c|c|c|c|c|c|c|c|}
\hline \multirow[b]{2}{*}{ Nest } & \multirow[b]{2}{*}{ Subnest } & \multirow{2}{*}{$\begin{array}{c}\text { No. of } \\
\text { chambers }\end{array}$} & \multicolumn{2}{|c|}{$\begin{array}{l}\text { Depth beneath ground } \\
\text { surface }(\mathrm{cm})\end{array}$} & \multicolumn{2}{|c|}{ Height $(\mathrm{cm})$} & \multicolumn{2}{|c|}{ Width $(\mathrm{cm})$} & \multirow{2}{*}{$\begin{array}{c}\text { Total } \\
\text { nest } \\
\text { depth } \\
(\mathrm{cm})\end{array}$} & \multirow{2}{*}{$\begin{array}{c}\text { Total } \\
\text { number of } \\
\text { chambers } \\
\text { per nest }\end{array}$} \\
\hline & & & Mean \pm SD & Range & Mean \pm SD & Range & Mean \pm SD & Range & & \\
\hline 1 & 1.1 & 2 & $19.8 \pm 13.1$ & $10.5-29$ & $5.5 \pm 2.1$ & $4-7$ & $7.8 \pm 1.8$ & $6.5-15.5$ & 46 & 2 \\
\hline \multirow[t]{2}{*}{2} & 2.1 & 3 & $25.7 \pm 12.3$ & $12-36$ & $8.5 \pm 4.3$ & $4.5-13$ & $8.2 \pm 2.8$ & $5.5-11$ & 49 & \\
\hline & 2.2 & 3 & $32.7 \pm 31.1$ & $12-36$ & $5.0 \pm 2.6$ & $4.5-13$ & $6.3 \pm 2.3$ & $5.5-11$ & 78 & 6 \\
\hline \multirow[t]{3}{*}{3} & 3.1 & 5 & $19.9 \pm 16.8$ & $8-140$ & $10.4 \pm 1.9$ & $8-2.5$ & $11.0 \pm 2.7$ & $8.5-15$ & 1.43 & \\
\hline & 3.2 & 3 & $10.1 \pm 16.0$ & $9-120$ & $9.0 \pm 2.6$ & $6-11$ & $6.3 \pm 2.1$ & $6-10$ & 1.30 & 11 \\
\hline & 3.3 & 3 & $16.7 \pm 17.7$ & $13-120$ & $8.7 \pm 1.3$ & $7.5-10$ & $9.0 \pm 4.0$ & $5-13$ & 1.35 & \\
\hline 4 & 4.1 & 3 & $26.2 \pm 16.2$ & $12.5-44$ & $5.0 \pm 2.6$ & $3-8$ & $6.7 \pm 1.2$ & $6-8$ & 49.5 & 3 \\
\hline 5 & 5.1 & 2 & $22.3 \pm 13.8$ & $12.5-32$ & $4.0 \pm 0$ & $4-4$ & $7.5 \pm 3.5$ & $5-10$ & 41 & 2 \\
\hline \multirow[t]{8}{*}{6} & 6.1 & 4 & $26.1 \pm 21.7$ & $6.5-55$ & $5.5 \pm 2.6$ & $2-8$ & $7.0 \pm 2.9$ & $4-10$ & 90 & \\
\hline & 6.2 & 4 & $27.5 \pm 16.3$ & $13-48$ & $7.3 \pm 1.0$ & $6-8$ & $9.6 \pm 2.4$ & $6.5-12$ & 56 & \\
\hline & 6.3 & 4 & $37.5 \pm 31.6$ & $13-82$ & $5.9 \pm 3.8$ & $2-6$ & $8.0 \pm 4.2$ & $3-12$ & 91 & \\
\hline & 6.4 & 4 & $39.8 \pm 35.9$ & $9-90$ & $6.3 \pm 1.0$ & $5-7$ & $6.8 \pm 2.2$ & $5-10$ & 96 & 33 \\
\hline & 6.5 & 5 & $17.0 \pm 7.8$ & $8-25$ & $4.2 \pm 1.3$ & $3-6$ & $7.3 \pm 2.7$ & $4-10$ & 30 & \\
\hline & 6.6 & 5 & $14.5 \pm 9.8$ & $6-30$ & $5.5 \pm 2.9$ & $2.5-9$ & $5.6 \pm 3.2$ & $3-11$ & 38 & \\
\hline & 6.7 & 3 & $20.0 \pm 24.4$ & $12-60$ & $3.2 \pm 1.5$ & $4-7$ & $5.1 \pm 2.2$ & $6-10$ & 62 & \\
\hline & 6.8 & 4 & $40.0 \pm 28.9$ & $10-75$ & $6.8 \pm 2.2$ & $5-10$ & $7.3 \pm 2.2$ & $4-9$ & 85 & \\
\hline 7 & 7.1 & 3 & $29.7 \pm 16.2$ & $15-47$ & $5.3 \pm 0.6$ & $5-6$ & $8.0 \pm 2.0$ & $6-10$ & 47 & 3 \\
\hline
\end{tabular}

SD: standard deviation.

Table 3. Number and dimensions (mean, standard deviation and range) of the internal tunnels of Acromyrmex balzani nests moulded with cement (measurement of tunnels between chambers).

\begin{tabular}{|c|c|c|c|c|c|c|c|}
\hline \multirow[b]{2}{*}{ Nest } & \multirow[b]{2}{*}{ Subnest } & \multirow[b]{2}{*}{ No. of tunnels } & \multicolumn{2}{|c|}{ Length (cm) } & \multicolumn{2}{|c|}{ Width $(\mathrm{cm})$} & \multirow{2}{*}{$\begin{array}{l}\text { Total number of } \\
\text { tunnels per nest }\end{array}$} \\
\hline & & & Mean \pm SD & Range & Mean \pm SD & Range & \\
\hline 1 & 1.1 & 3 & $12.3 \pm 5.9$ & $8-19$ & $0.8 \pm 0.3$ & $0.6-1.1$ & 3 \\
\hline \multirow[t]{2}{*}{2} & 2.1 & 3 & $12.5 \pm 3.1$ & $10-16$ & $0.6 \pm 0$ & 0.6 & 6 \\
\hline & 2.2 & 3 & $23.2 \pm 19.6$ & $7-45$ & $0.8 \pm 0.4$ & $0.6-1.3$ & \\
\hline \multirow[t]{3}{*}{3} & 3.1 & 3 & $29.8 \pm 40.9$ & $5.5-77$ & $0.6 \pm 0.6$ & $0.6-1.1$ & \\
\hline & 3.2 & 3 & $37.0 \pm 40.1$ & $9-83$ & $0.4 \pm 0$ & 0.6 & 9 \\
\hline & 3.3 & 3 & $35.2 \pm 33.8$ & $12.5-74$ & $1.6 \pm 0.5$ & $1.3-2.2$ & \\
\hline 4 & 4.1 & 3 & $10.5 \pm 5.6$ & $7.0-17$ & $1.1 \pm 0$ & 1.1 & 3 \\
\hline 5 & 5.1 & 2 & $13.5 \pm 2.1$ & $12-27$ & $1.2 \pm 0$ & 1.2 & 2 \\
\hline \multirow[t]{8}{*}{6} & 6.1 & 5 & $12.8 \pm 8.1$ & $9-23$ & $1.6 \pm 0.8$ & $1.2-3.1$ & \\
\hline & 6.2 & 5 & $10.0 \pm 6.1$ & 4-18 & $1.2 \pm 0$ & 1.2 & \\
\hline & 6.3 & 4 & $19.0 \pm 14.2$ & $10-40$ & $1.5 \pm 0.7$ & $1.1-2.5$ & \\
\hline & 6.4 & 4 & $19.8 \pm 18.6$ & $8-47$ & $1.4 \pm 0.6$ & $1.1-2.2$ & \\
\hline & 6.5 & 4 & $9.3 \pm 3.9$ & $8-15$ & $1.3 \pm 0.4$ & $1.1-2.0$ & 31 \\
\hline & 6.6 & 2 & $11.0 \pm 7.1$ & $6-16$ & $1.0 \pm 0$ & 1.0 & \\
\hline & 6.7 & 3 & $13.2 \pm 10.5$ & $5-25$ & $1.4 \pm 0.7$ & $1.0-2.2$ & \\
\hline & 6.8 & 4 & $16.8 \pm 7.9$ & $10-25$ & $1.3 \pm 0.6$ & $1.0-2.1$ & \\
\hline 7 & 7.1 & 3 & $11.7 \pm 11.6$ & $4.1-25$ & $0.9 \pm 0$ & 0.9 & 3 \\
\hline
\end{tabular}

SD: standard deviation.

found aggregated on Brachiaria sp. and Paspalum sp. pastures and consisted of one to eight subnests (Figures 3-12).

During the study period, waste was always deposited outside the nest, near the mound of loose soil or around the entrance hole. This waste consisted of exhausted plant fragments, which were used for cultivation of the fungus, and dead ants. The intensity of waste deposition was higher between January and July, but waste deposition was observed throughout the study period. 


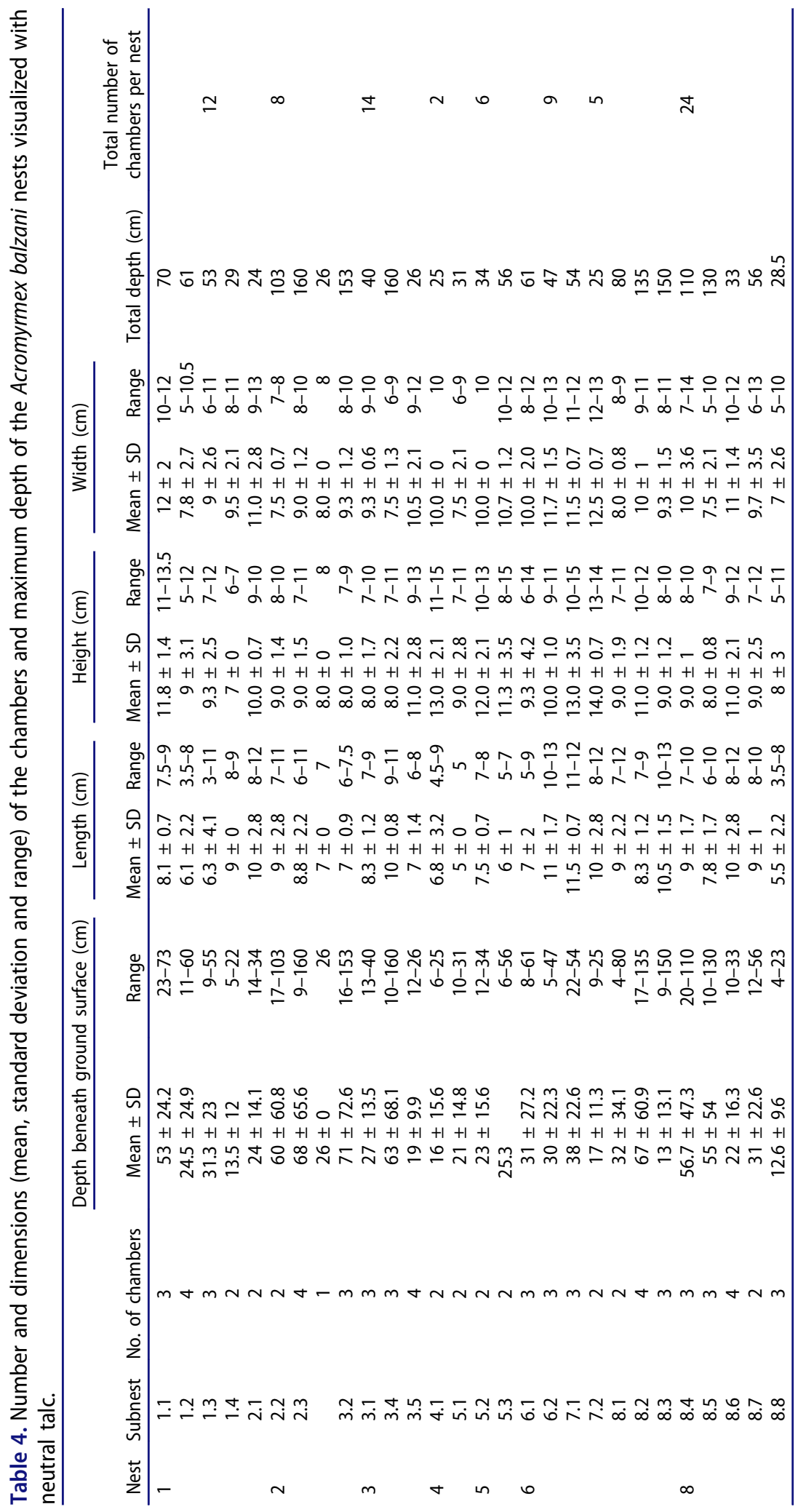



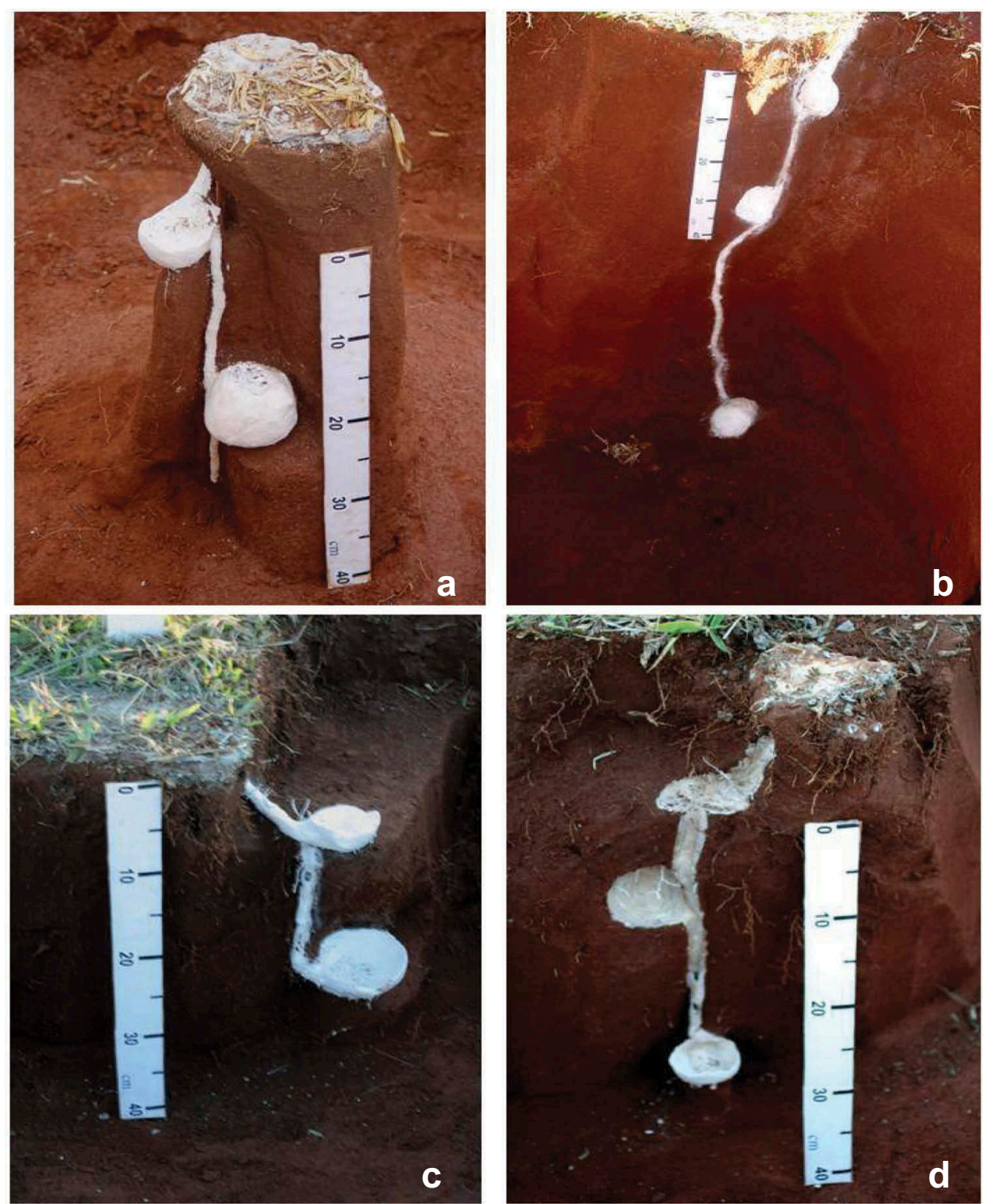

Figure 2. Nests moulded with cement. (A) Nest 1 containing two chambers; (B) nest 7 containing three chambers; $(C)$ nest 4 containing two chambers; (D) nest 5 containing three chambers. Scale: $40 \mathrm{~cm}$.

\section{Aggressiveness test}

When concolonial workers were confronted, aggressiveness was not observed $(74.07 \%$ of observations without aggressiveness $\left.X^{2}=18.78, p<005\right)$. In contrast, when allocolonial workers were confronted, there was a high incidence of aggression among them (94.16\% of observations with aggressiveness, $X^{2}=106.87, p<005$ ). 

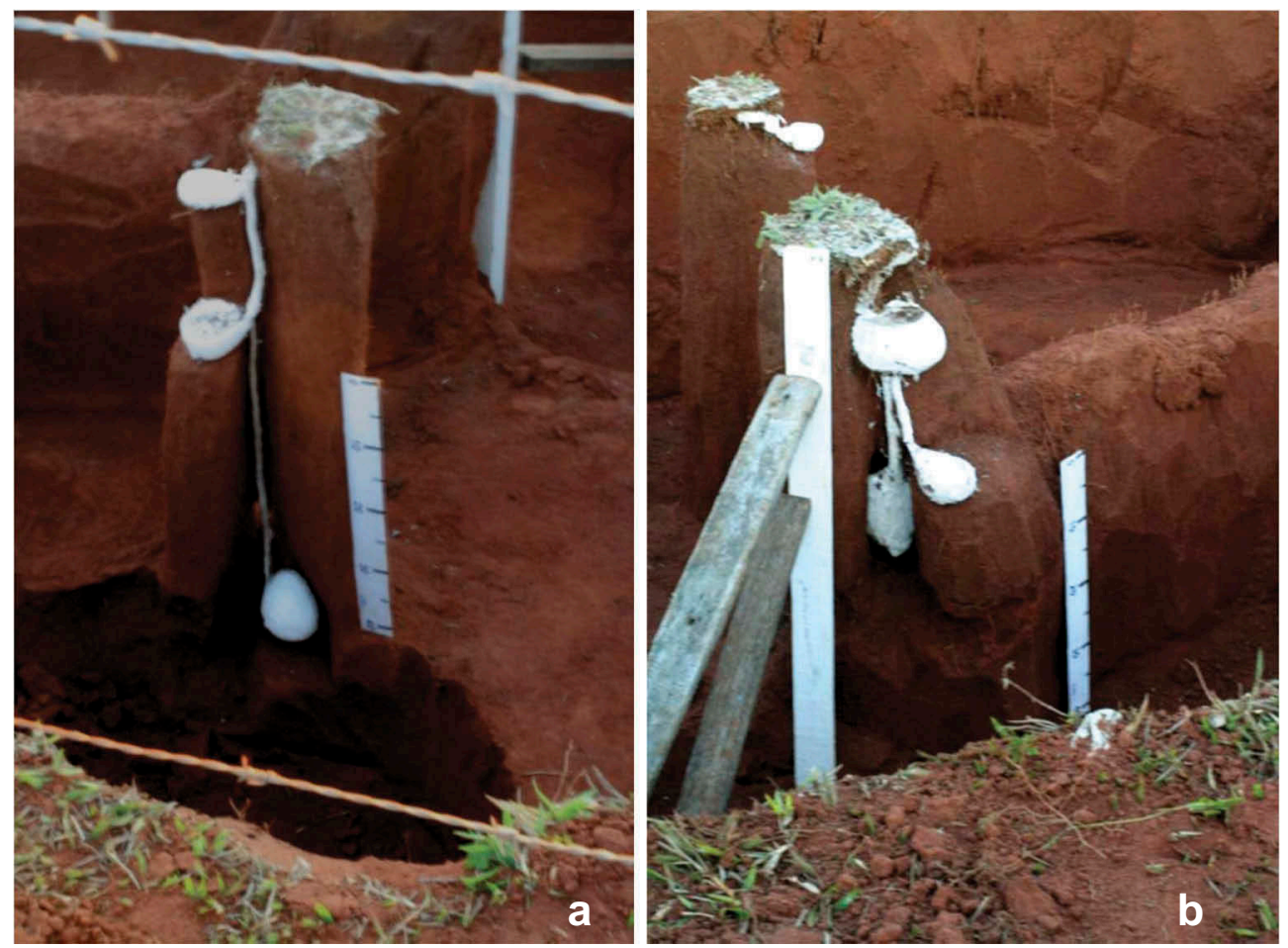

Figure 3. Nest 2 moulded with cement. (A) Subnest 1 containing three chambers; (B) subnest 2 containing three chambers. Scale: $40 \mathrm{~cm}$.

\section{Determination of colony population}

There was only one queen for each polydomous nest, i.e. subnests with a single queen. The total population in the five colonies varied from 337 to 2832 individuals (Table 5). The fungus volume in the excavated nests varied from 35.07 to $147.8 \mathrm{ml}$; The mean number of eggs was 60, mean number of of larvae was 130.4 and of pupae was 139.0 individuals. There were no winged individuals in the excavated nests. The smaller workers were more prevalent in all nests observed taking into account the total population (Table 1). The volume of fungus was positively correlated with the number of individuals $(y=23.1 x-631.37, R=96.66 \%)$ and the number of workers $(y=17.161 x-$ $516.78, R=95.31 \%)$, indicating that the fungus volume increases in direct proportion with the population in the nest.

\section{Discussion}

The external architecture of polydomous A. balzani nests possessed the typical pattern, with the presence of a single entrance of irregular shape and variable size in each subnest. A mound of loose soil derived from the tunnels and galleries could be observed near the entrance during some months of the year, generally in summer (December to March). These findings agree with those described by Mendes et al. (1992) for the same species in the region of Coimbra, Zona da Mata, Minas Gerais. However, no deposition of 

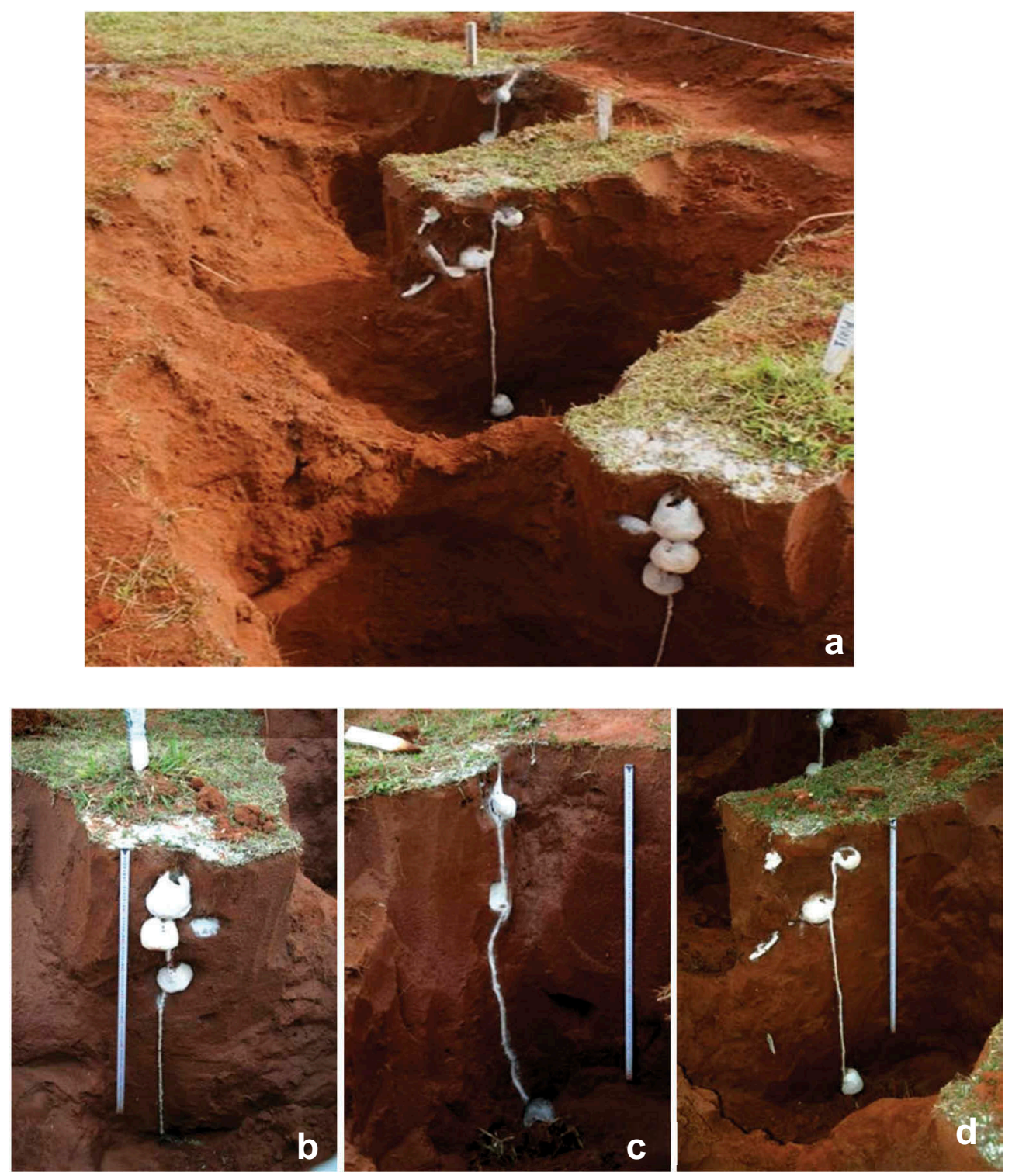

Figure 4. (A) General view of nest 3 moulded with cement; (B) general view of subnest 1 ; (C) general view of subnest 2; (D) general view of subnest 3. Scale: $1.5 \mathrm{~m}$.

loose soil near the entrance was observed during colder periods of the year (June to August). Pimenta et al. (2007) also found no typical straw tube at the entrance of the nests during the dry periods of the year, especially August, September and October. According to these authors, the nest entrance was characterized by the presence of dry plant fragments and small lumps of soil, which was not observed in the present study. Gonçalves (1961) conducted a survey of this species in different states of Brazil and observed a straw tube only in some regions. 


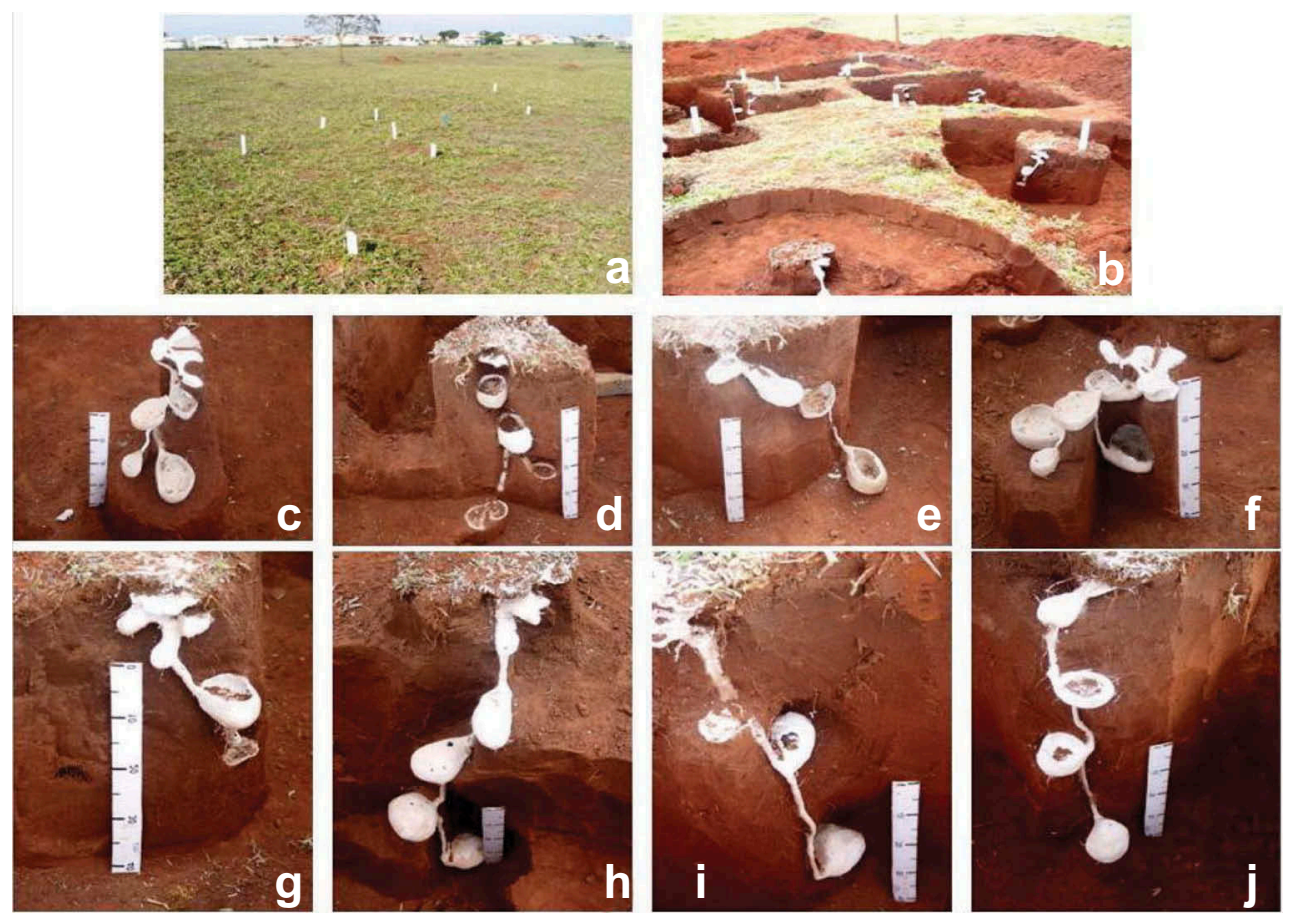

Figure 5. (A) External view of nest 6 moulded with cement; (B) view of excavation of nest 6 ; (C) subnest 1 ; $(D)$ subnest 2; $(E)$ subnest 3 ; $(F)$ subnest 4; $(G)$ subnest 5 ; $(H)$ subnest 6 ; (I) subnest 7; (J) subnest 8 . Scale: $40 \mathrm{~cm}$.

The differences in the deposition of loose soil are probably related to differences in the climate of the region, type of soil and nesting. Hence, this species would only deposit loose soil when the environmental conditions were favourable. No soil deposition occurs during the colder and drier periods of the year because the colony reduces its activities during this period to save energy because of the scarcity of food.

Acromyrmex balzani ants construct simple underground nests consisting of a defined system of tunnels and chambers. These nests are relatively small when compared with the nests of other species of the genus Acromyrmex. The nests of $A$. balzani ants do not possess internal shafts, whereas in nests of $A$. rugosus rugosus a single chamber can be connected by several tunnels of different sizes that can be vertical or horizontal. These tunnels pass alongside the chambers, branching and giving origin to shorter tunnels (Verza et al. 2007). In contrast, in Atta species the internal communication of the colony is performed through a network of channels (Moreira et al. 2004a). In the case of A. balzani, this communication between the subnests of a colony is performed by workers that walk from one hole to the other on the external part of the nests, while the queen remains in only one subnest together with the brood.

There is a small first shaft between the entrance hole and the first chamber, which is generally short and wider than the other tunnels found, measuring on average $1.2 \mathrm{~cm}$ in diameter and $15.5 \mathrm{~cm}$ in length. This shaft connects the entrance hole to the first chamber. The excavated nests had a depth of 30-160 cm and one to five chambers, with three chambers being the most frequent. Our findings regarding the number of 

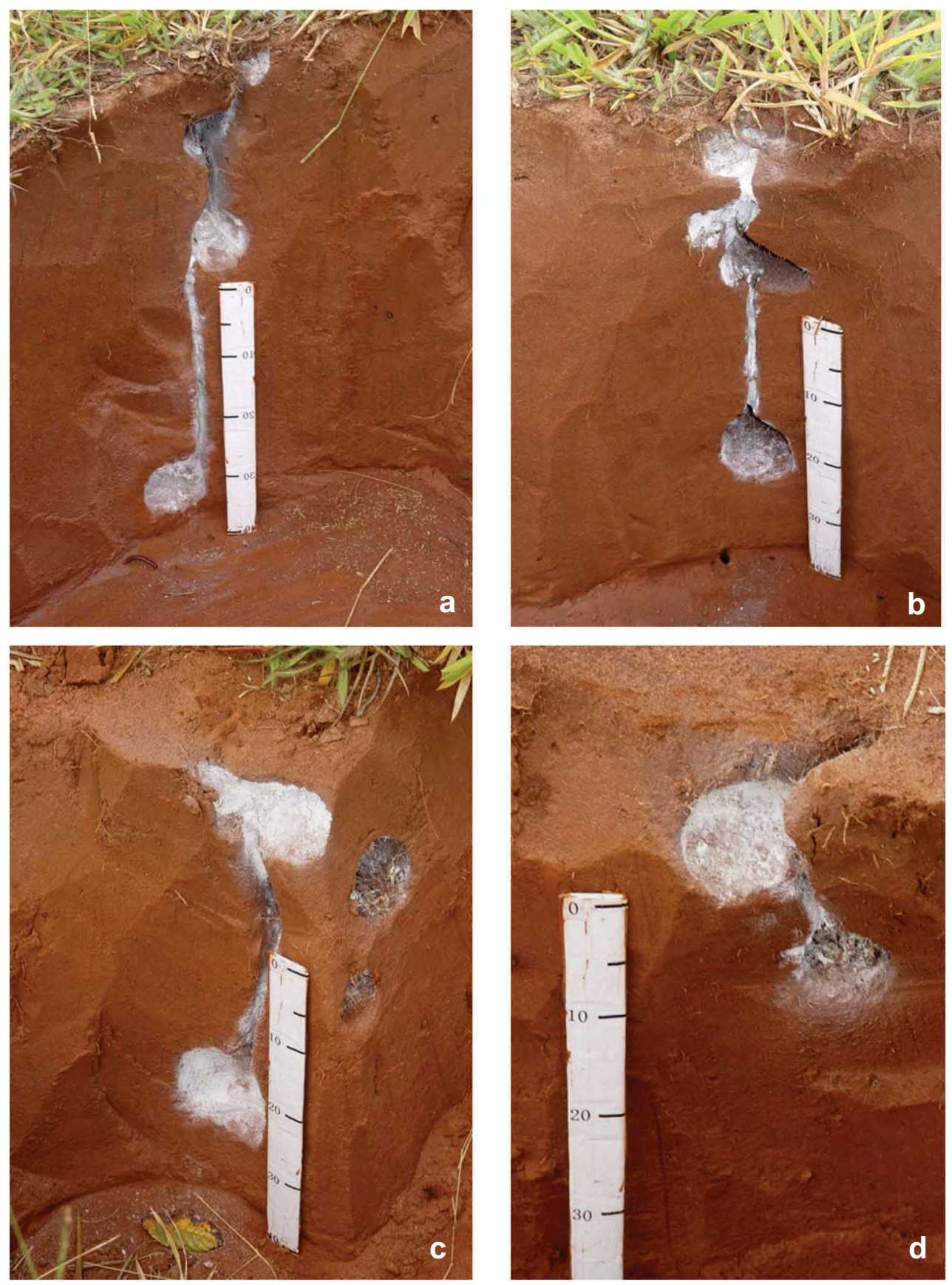

Figure 6. Nest 1a (A-D). General view of the subnests of colony 1 of Acromyrmex balzani. Scale: $40 \mathrm{~cm}$.

chambers agree with those reported by Mendes et al. (1992) in the region of Zona da Mata (MG) and by Pimenta et al. (2007), but differ from those reported by Silva et al. (2010) in the southwestern region of Bahia who found nests with up to 14 chambers. 

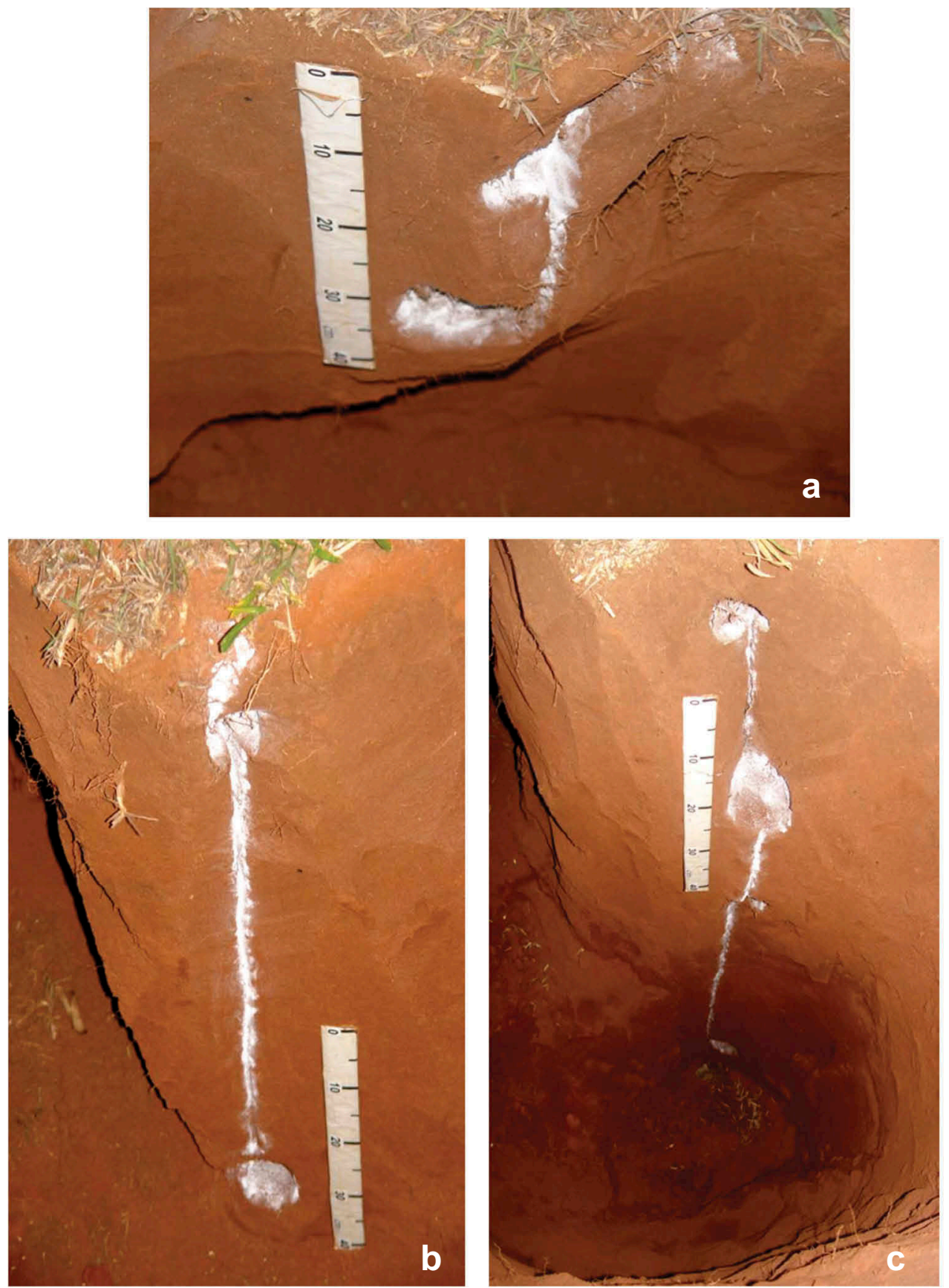

Figure 7. Nest 2a $(A-C)$. General view of the subnests of nest 2 of Acromyrmex balzani. Scale: $40 \mathrm{~cm}$.

The difference in the number of chambers between locations is probably related to the climate of each region, type of soil and nesting of this species.

With respect to their arrangement, the chambers always overlapped and were connected by a single vertical shaft. In contrast, in A. rugosus rugosus chambers with lateral 

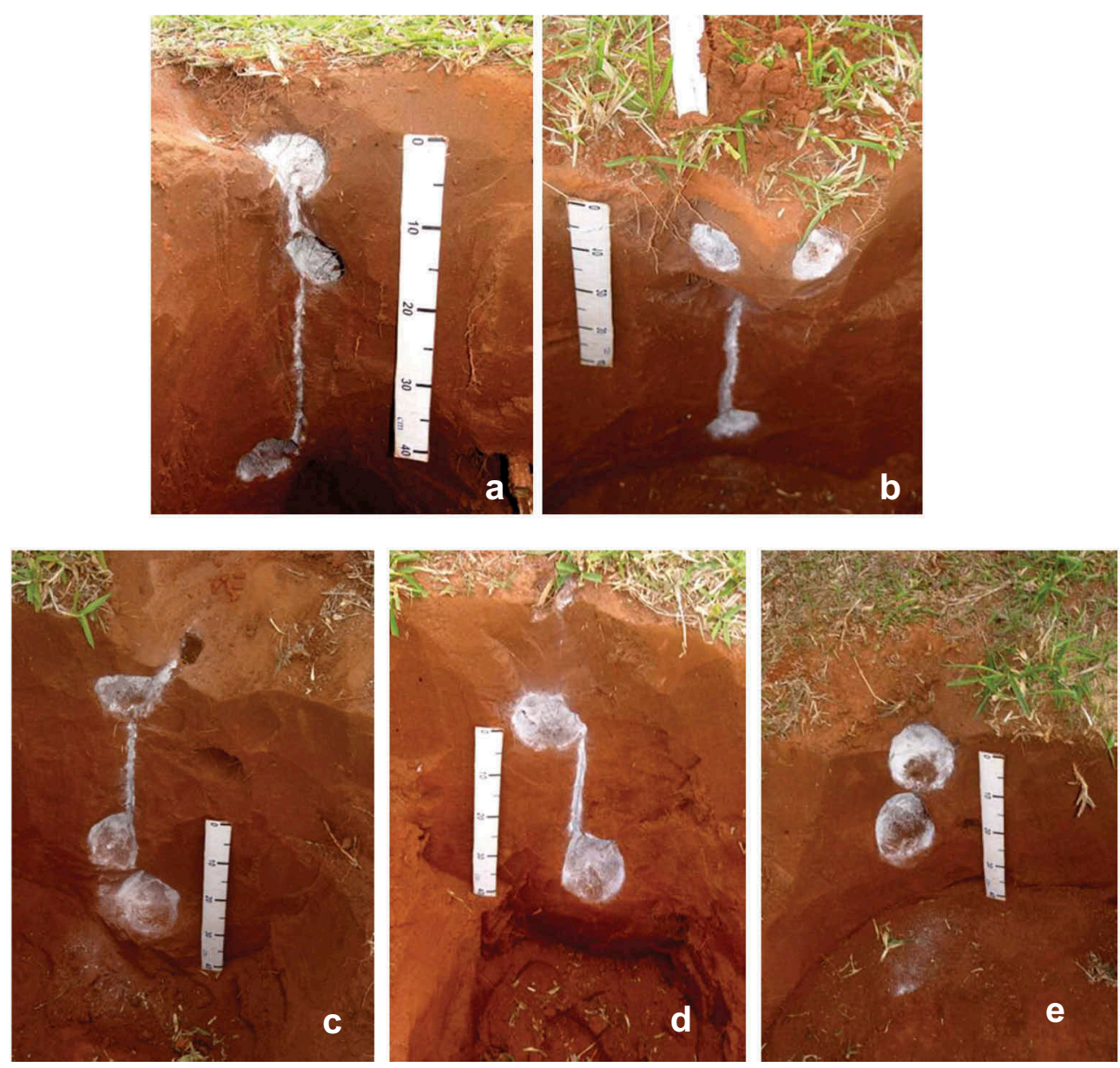

Figure 8. Nest 3a (A-E). General view of the subnests of colony 3 of Acromyrmex balzani. Scale: $40 \mathrm{~cm}$.

openings are often observed, which lead to another chamber that normally contains the fungus (Gonçalves 1961; Verza et al. 2007). The number of excavated nests permitted us to observe that the morphology of the chambers in different nests is similar, a fact suggesting a unique pattern of nest construction in this ant species. The variation in the number of chambers is probably related to the age of the colony.

Fungal mass and workers were found in most of the chambers excavated without cement. However, immature stages (eggs, larvae and pupae) were only observed in chambers where the queen was present, which was usually located in the last chamber in the case of deeper nests. According to Pimenta et al. (2007), fungal mass is not found in the first chamber. Empty chambers were also observed in the present study, but they were not always the first chamber and the number of these chambers was variable.

No immature stages (larvae and pupae), only adult workers, were detected in some nests between June and September 2009. The amount of fungus was very small in some excavated chambers. These findings agree with Ichinose et al. (1995) who concluded that A. balzani divides its biological cycle into two seasons, one consisting of a population of immature stages and another consisting only of adults. The amount of cultivated fungus is higher $(6-7 \mathrm{~g}$ dry 

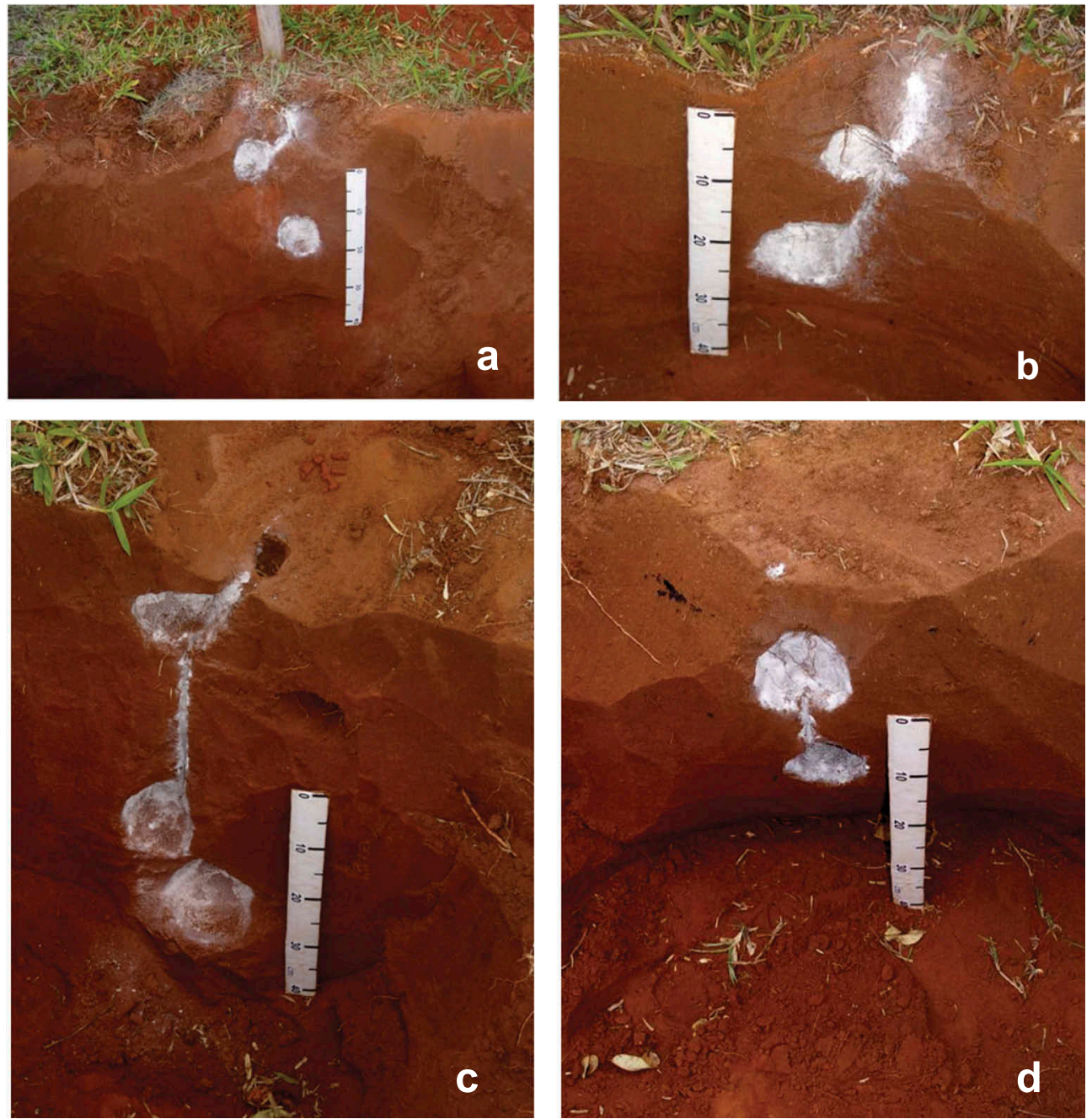

Figure 9. Nests 4 and 5a. (A) General view of subnest 1, nest 4; (B) general view of subnest 1, nest 5; (C) general view of subnest 2, nest 5; (D) general view of subnest 3, nest 5 . Scale: $40 \mathrm{~cm}$.

weight) during the period when the production of immature stages is more intense, whereas the amount of fungus does not exceed $3 \mathrm{~g}$ during other periods.

Acromyrmex balzani does not possess waste chambers. The waste is deposited outside the nest as observed throughout the study period. External waste deposition is also found in other Acromyrmex species, such as Acromyrmex coronatus, Acromyrmex fracticornis, Acromyrmex hispidus, Acromyrmex landolti, Acromyrmex lobicornis, Acromyrmex lundi pubences, Acromyrmex striatus and Acromyrmex subterraneus (Bonetto 1959; Gonçalves 1961; Zolessi and Abenante 1973; Zolessi and Gonzáles 1974; Fowler and Robinson 1979; Pereira-da-Silva et al. 1981; Navarro and Jaffé 1985; Della Lúcia and Moreira 1993; Farji-Brener 2000; Andrade 2002).

In conclusion, polydomous nests of $A$. balzani are characterized by: (a) the nest has many subnests, not interconnected with tunnels; (b) the concolonial workers are not 

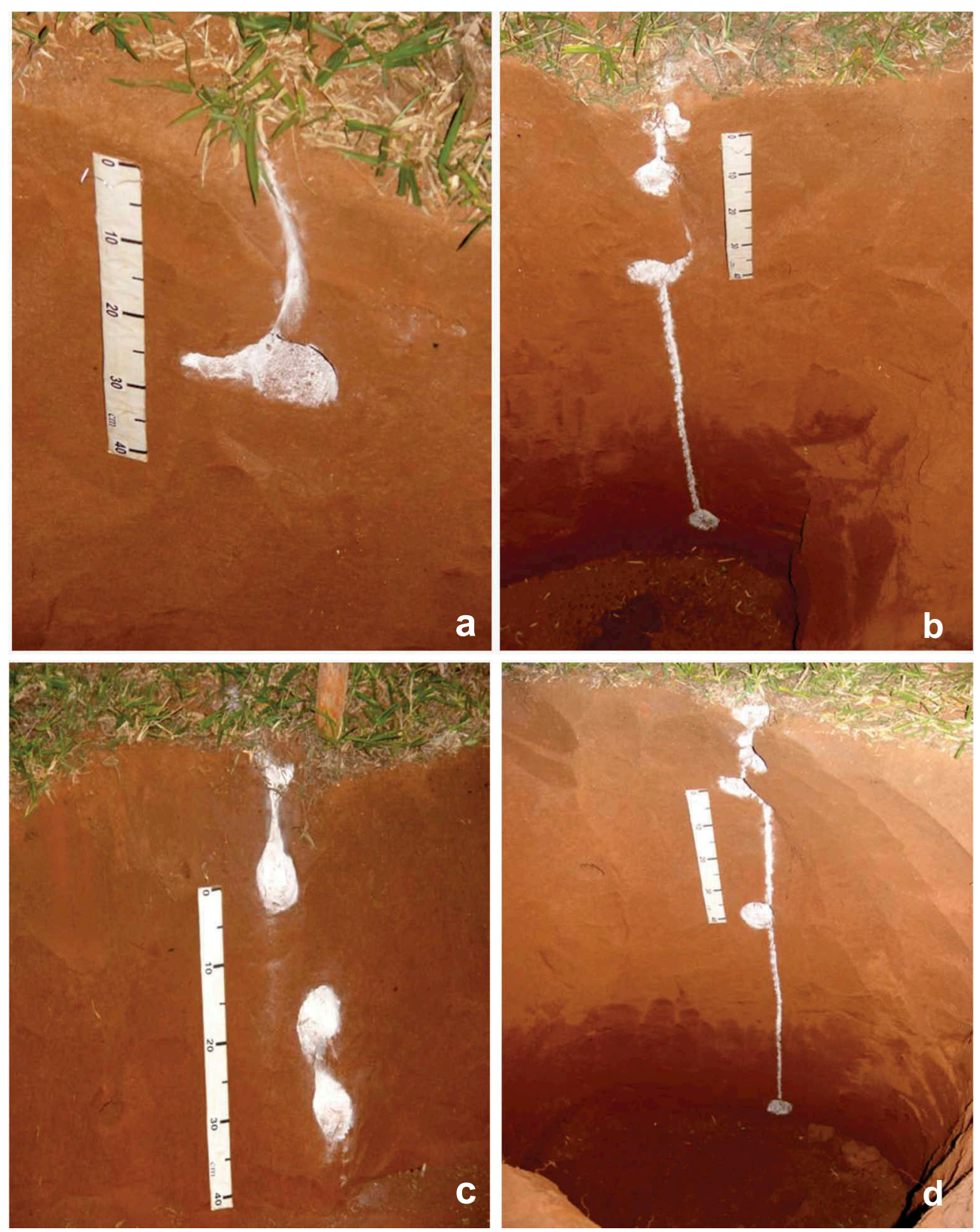

Figure 10. Nests 6 and 7a. (A) General view of subnest 1, nest 6; (B) general view of subnest 2, nest 6; (C) general view of subnest 1, nest 7; (D) general view of subnest 2, nest 7 . Scale: $40 \mathrm{~cm}$.

aggressive among themselves, whereas allocolonial workers are aggressive; (c) there is only one queen for each polydomous nest, i.e. subnests have a single queen. Finally, the colonies lives physically separated but socially connected in subnests.

Our study contributes to a better understanding of the so far unknown nest architecture of the polydomous grass-cutting ant $A$. balzani. 


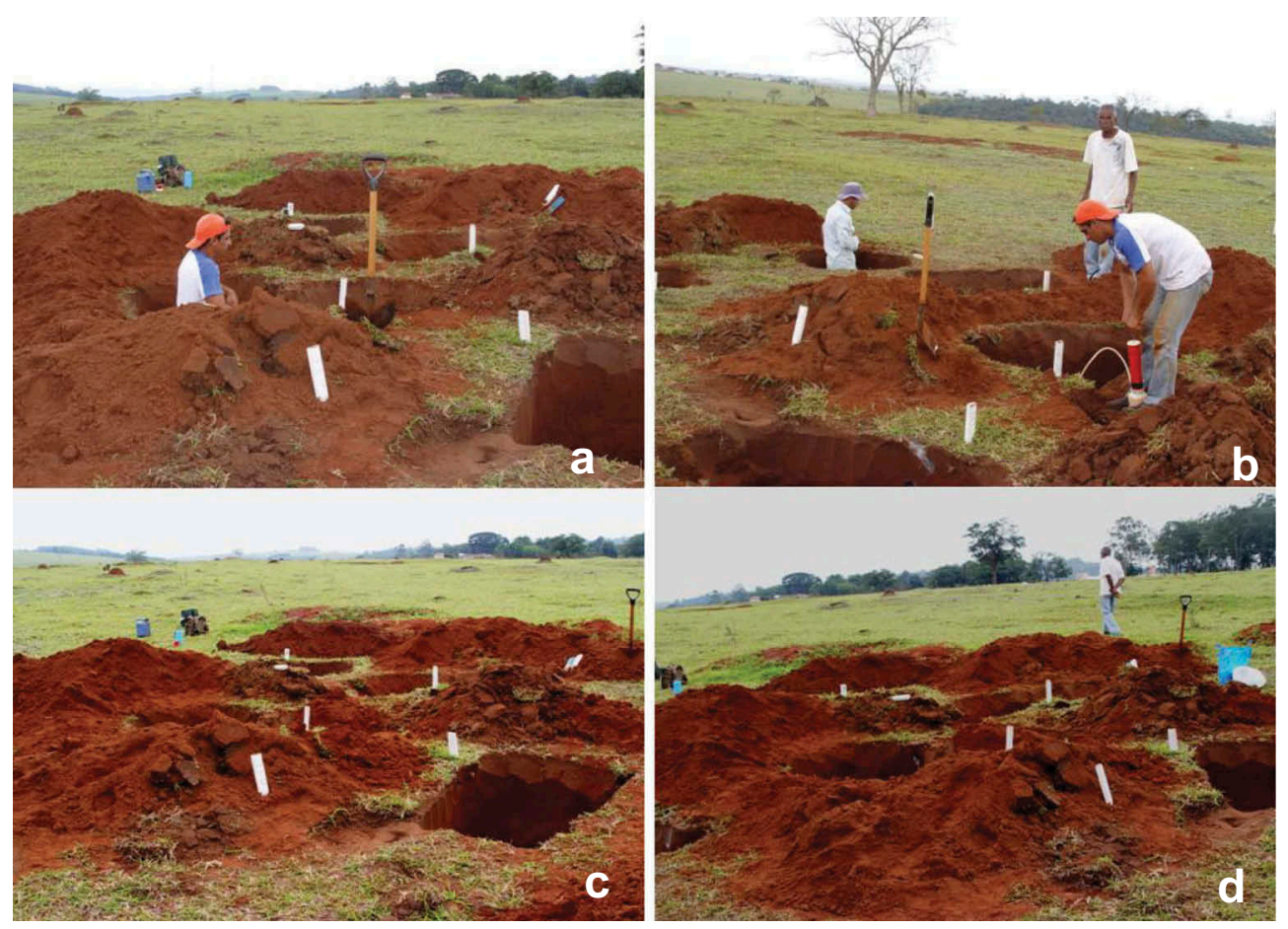

Figure 11. General view of excavation of nest 8 a.
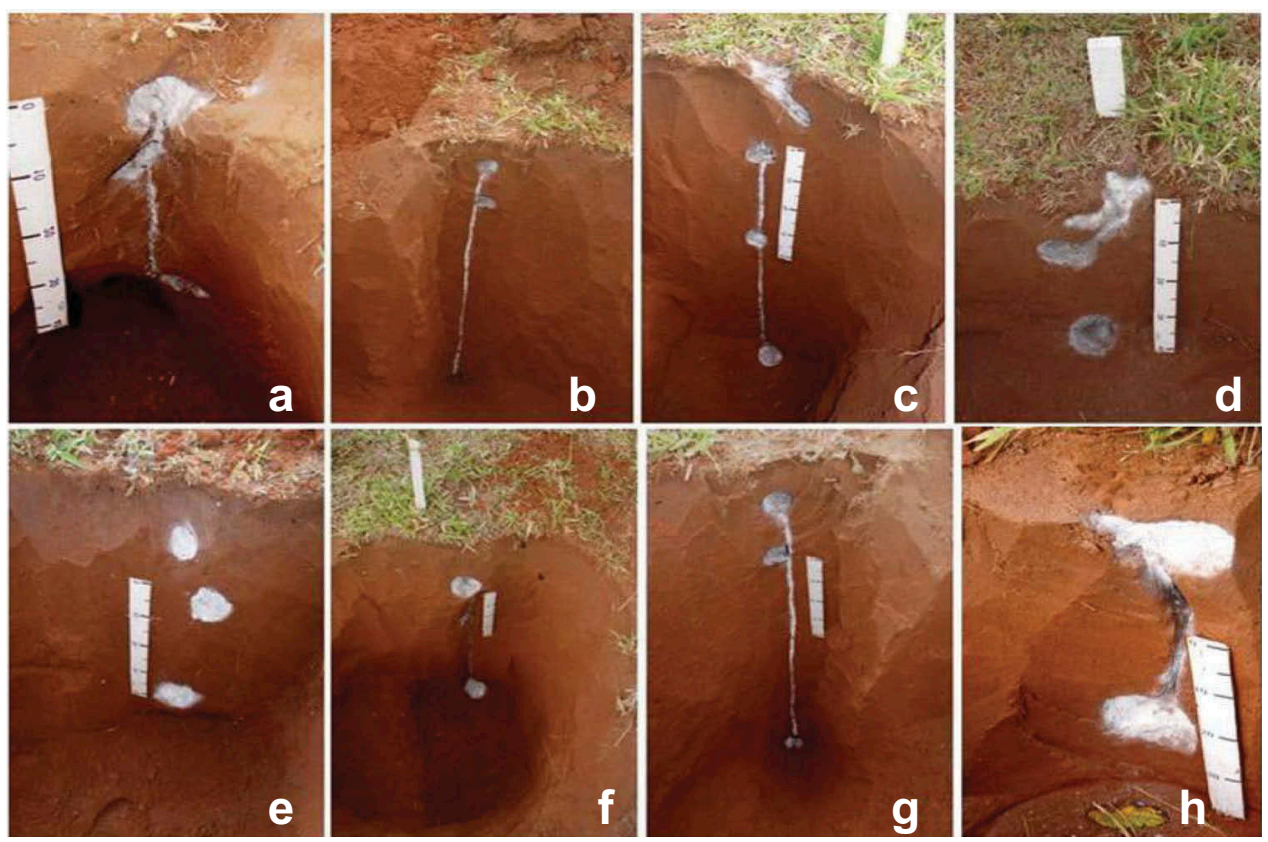

Figure 12. General view of nest 8 a. (A) Subnest 1 ; (B) subnest 2; (C) subnest 3 ; (D) subnest 4; (E) subnest 5 ; $(\mathrm{F})$ subnest 6 ; $(\mathrm{G})$ subnest $7 ;(\mathrm{H})$ subnest 8 . Scale: $40 \mathrm{~cm}$. 


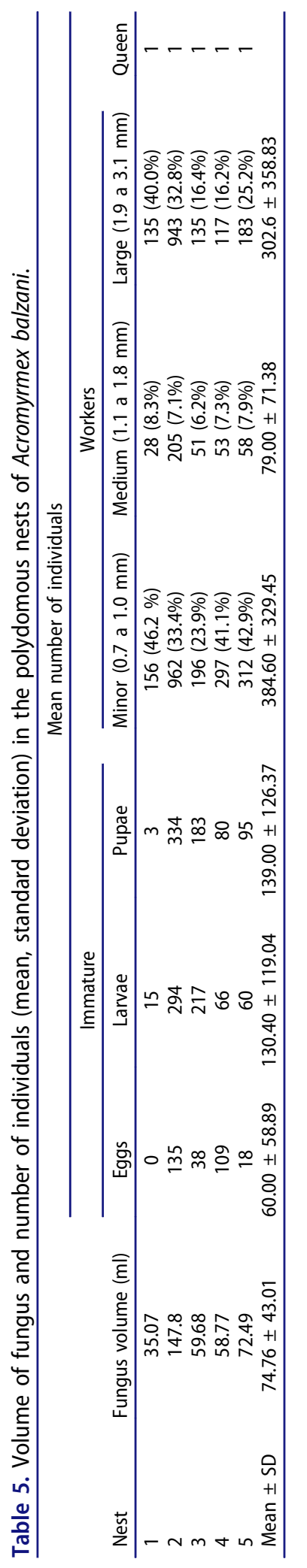




\section{Disclosure statement}

No potential conflict of interest was reported by the authors.

\section{Funding}

We thank the state funding agency Fundação de Amparo à Pesquisa do Estado de São Paulo (FAPESP) for financial support and for the fellowships granted to the authors (grants 07/07091-0 and 07/04010-0). LCF was the recipient of a grant from Conselho Nacional de Desenvolvimento Cientifico e Tecnológico (grant 301718/2013-0).

\section{References}

Andrade APP. 2002. Biologia e Taxonomia Comparadas das subespécies de Acromyrmex subterraneus Forel, 1893 (Hym., Formicidae) e contaminação das operárias por iscas tóxicas [Dissertação (Doutorado em Ciências Biológicas/Zoologia)]. Botucatu: Instituto de Biociências, Universidade Estadual Paulista.

Bollazzi M, Roces F. 2002. Thermal preference for fungus culturing and brood location by workers of the thatching grass-cutting ant Acromyrmex heyeri. Insect Soc. 49:153-157.

Bonetto A. 1959. Las hormigas "cortadoras" de la provincia de Santa Fé (Generos: Atta y Acromyrmex). Direccion General de Recursos Naturales. 2:17-26.

Della Lúcia TMC, Moreira DDO. 1993. Caracterização dos ninhos. In: Dellalúcia TMC, editor. As formigas cortadeiras. Viçosa: Folha de Viçosa; p. 32-42.

Farji-Brener AGF. 2000. Leaf-cutting ant nests in temperature environments: mounds, mound damage and nest mortality rate in Acromyrmex lobicornis. Stud Neutrop Fauna Environm. 35:131-138.

Forti LC, Andrade ML, Andrade APP, Juliane FSL, Ramos VM. 2006. Bionomics and identification of Acromyrmex (Hymenoptera: Formicidae) through an illustrated key. Sociobiology. 48:135-153.

Fowler HG, Pereira da Silva V, Forti LC, Saes NB. 1986. Population dynamics of leaf-cutting ants: a brief review. In: Lofgren CS, Vandemeer RK, editors. Fire ants and leaf-cutting ants. Boulder: Westiview; p. 123-145.

Fowler HG, Robinson SW. 1979. Foraging by Atta sexdens (Formicidae: Attini): seasonal patterns, caste and efficiency. Ecol Entomol. 4:239-247.

Gonçalves CR. 1961. O gênero Acromyrmex no Brasil (Hymenoptera, Formicidae). Studia Entomológica. 4:113-180.

Gonçalves CR. 1964. As formigas cortadeiras. Boletim de Campo, Rio de Janeiro. 20:7-23.

Halley JD, Burd M, Well P. 2005. Excavation and architecture of Argentine ant nests. Insect Soc. 52:350-356.

Hölldobler B, Wilson EO. 1990. The ants. Cambrigde (MA): Harvard University Press; p. 133-154.

Ichinose K, Forti LC, Pretto DR. 1995. Ciclo biológico anual de Acromyrmex balzani, Em Botucatu, SP, Brasil. Caxambu (MG): Anais do $15^{\circ}$ Congresso de Entomologia; p. 146.

Ichinose K, Forti LC, Pretto DR, Nachman G, Boomsma JJ. 2007. Sex allocation in the polydomous leaf-cutting ant Acromyrmex balzani. Ecol Res. 22:288-295.

Jacoby M. 1935. Erforschug der Struktur des Atta Nests mit Hilfe des Cementausguss-Verfahrens. Rev Entomol. 5:5-420.

Jacoby M. 1950. A arquitetura do ninho. In: Jacoby M, editor. A saúva: uma inteligência nociva. Rio de Janeiro (Brasil): Serviço de Informação Agrícola; p. 21-31.

Kleineidam C, Roces F. 2000. Carbon dioxide concentrations and nest ventilation in nests of the leaf-cutting ant Atta vollenweideri. Insect Soc. 47:241-248.

Mendes WBA, Freire JAH, Loureiro MC, Nogueira SB, Vilela EF, Della Lucia TMC. 1992. Aspectos ecológicos de Acromyrmex (Moellerius) balzani (Emery, 1890) (Formicidae: Attini) no município de São Geraldo, Minas Gerais. Anais da Sociedade Entomológica do Brasil. 21:155-168. 
Mikheyev AS, Tschinkel WR. 2004. Nest architecture of the ant Formica pallidefulva: structure, costs and rules of excavation. Insect Soc. 51:30-36.

Moreira AA. 1996. Arquitetura das colônias de Atta laevigata Fr. Smith, 1858 (Hymenoptera, Formicidae) e distribuição de substrato nas câmaras de fungo [Tese (Mestrado)]. Botucatu: Faculdade de Ciências Agronômicas; 96p.

Moreira AA. 2001. Atta bisphaerica Forel, 1908 (Hym: Formicidae): arquitetura de ninhos e distribuição de isca nas câmaras [Ph.D. Thesis]. Botucatu: Faculdade de Ciências Agronômicas, UNESP; $87 \mathrm{p}$.

Moreira AA, Forti LC, Andrade APP, Boaretto MAC, Lopes JFS. 2004a. Nest architecture of Atta laevigata (F. Smith, 1858) (Hymenoptera: Formicidae). Stud Neotropical Fauna Environ. 39:109116.

Moreira AA, Forti LC, Boaretto MAC, Andrade APP, Lopes JFS, Ramos VM. 2004b. External and internal structure of Atta bisphaerica Forel (Hymenoptera: Formicidae) nests. J Appl Entomol. 128:204-211.

Moser JC. 2006. Complete excavation and mapping of the Texas leaf cutting ant nest. Ann Entomol Soc Am. 99:891-897.

Navarro JG, Jaffé K. 1985. On the adaptive value of nest features in the grass-cutting ant Acromyrmex landolti. Biotropica. 17:347-348.

Pereira-da-Silva V, Forti LC, Cardoso LG. 1981. Dinâmica populacional e caracterização de ninhos de Acromyrmex coronatus (Fabricius, 1804) (Hymenoptera: Formicidae). Revista Brasileira Entomologia. 25:87-93.

Pimenta LB, Araújo MS, Lima L, Silva JMS, Naves VGO. 2007. Dinâmica de forrageamento e caracterização de colônias de Acromyrmex balzani (Emery, 1890) (Hymenoptera: Formicidae) em ambiente de cerrado goiano. Revista Cientifica Eletrônica de Engenharia Florestal. 9:1-12.

Roces F, Kleineidam C. 2000. Humidity preference for fungus culturing by workers of the leafcutting ant Atta sexdens rubropilosa. Insect Soc. 47:348-350.

Silva KS, Castellani MA, Forti LC, Moreira AA, Lemos OL, Carneiro RC, Khouri CR, Ribeiro AEL. 2010. Arquitetura de ninhos de Acromyrmex (Moellerius) balzani (Formicidae: Myrmicini: Attini) em Pastagem. Pesquisa Aplicada \& Agrotecnologia (Impresso). 3:99-106.

Sudd JH. 1982. Ants: foraging, nesting, brood behavior, and polyethism. In: Hermann HR, editor. Social insect. Vol. 4. New York (NY): Academic Press; p. 107-155.

Tschinkel WR. 1987. Seasonal life history and nest architecture a winter-active ant, Prenolepis imparis. Insect Soc. 34:143-164.

Tschinkel WR. 1999a. Sociometry and sociogenesis of colonies of the harvester ant, Pogonomyrmex badius: distribution of workers, brood and seeds within the nest in relation to colony size and season. Ecol Entomol. 24:222-237.

Tschinkel WR. 1999b. Sociometry and sociogenesis of colony-level attributes of the Florida harvester ant (Hymenoptera: Formicidae). Ann Entomol Soc Am. 92:80-89.

Tschinkel WR. 2003. Subterranean ant nests: trace fossils past and future? Palaeogeogr Palaeoclimatol Palaeoecol. 192:321-333.

Tschinkel WR. 2004. The nest architecture of the Florida harvester ant, Pogonomyrmex badius. J Insect Sci. 4:1-19.

Tschinkel WR. 2005. The nest architecture of the ant Camponotus socius. J Insect Sci. 5:1-18.

Verza SS, Forti LC, Lopes JFS, Hughes WO. 2007. Nest architecture of the leaf cutting ant Acromyrmex rugosus rugosus. Insect Soc. 54:303-309.

Weber NA. 1972. Gardening ants: the attines. Philadelphia (PA): Mem. Am. Philos. Soc.; p. 146 pp.

Zolessi LC, Abenante YP. 1973. Nidificacion y mesoetologia de Acromyrmex en el Uruguay. III. Acromyrmex (A.) hispidus Santschi, 1925 (Hymenoptera: Formicidae). Revista de Biología do Uruguay. 1:151-165.

Zolessi LC, Gonzáles LA. 1974. Nidificacion y mesoetologia de Acromyrmex en el Uruguay. II. Acromyrmex (A.) lobicornis (Emery, 1887) (Hymenoptera: Formicidae). Revista de Biología do Uruguay. 1:37-54. 